\title{
PENGELOLAAN DESA WISATA BERBASIS PARTISIPASI MASYARAKAT LOKAL DI NEGERI SALEMAN KABUPATEN MALUKU TENGAH
}

\author{
Rachmat Hidayat Romeon ${ }^{1 *}$, Annisa Mu'awanah Sukmawati² \\ Program Studi Perencanaan Wilayah dan Kota, Universitas Teknologi Yogyakarta ${ }^{1,2}$ \\ Jalan Glagahsari No. 63, Warungboto, Umbulharjo, Kota Yogyakarta 55164 \\ e-mail*: rachmatromeon@gmail.com
}

\begin{abstract}
ABSTRAK
Negeri Saleman merupakan salah satu wilayah yang terletak di Desa Sawai, Kecamatan Seram Utara, Kabupaten Maluku Tengah, Provinsi Maluku yang memiliki beragam potensi alam berupa wisata pantai dan wisata bahari. Namun, wisata di Negeri Saleman belum terkelola dengan baik karena masih terbatasnya keterlibatan pemerintah daerah. Wisata-wisata yang ada masih dikelola secara mandiri oleh masyarakat setempat. Untuk itu, penelitian bertujuan untuk menggali bentuk-bentuk partisipasi masyarakat lokal dalam pengelolaan potensi wisata di Negeri Saleman. Penelitian menggunakan metode penelitian kualitatif dengan teknik analisis deskriptif kualitatif. Pengumpulan data dilakukan dengan observasi lapangan, wawancara mendalam dengan teknik purposive sampling kepada 7 informan, dan telaah dokumen. Hasil penelitian menunjukan bahwa bentuk partisipasi masyarakat lokal Negeri Saleman adalah sebagai pelaku utama pariwisata, seperti penyedia jasa akomodasi wisata dan oleh-oleh khas Negeri Saleman. Selain itu, ada juga peran dari local champion, yaitu tokoh adat dan Bapa Raja yang berperan sebagai pengawas dan pengendali aktivitas wisata agar keberlanjutan aktivitas wisata dapat terjamin. Faktor yang mendorong keterlibatan masyarakat lokal adalah motif ekonomi terkait dampak ekonomi wisata terhadap peningkatan taraf hidup masyarakat setempat.
\end{abstract}

Kata Kunci: desa wisata, Kabupaten Maluku Tengah, Negeri Saleman, partisipasi masyarakat.

\section{ABSTRACT}

Negeri Saleman is one of the areas located in Sawai Village, North Seram District, Central Maluku Regency, Maluku Province which has various natural potentials; they are beach and marine tourism. However, these tourism potentials in Negeri Saleman have not been well managed due to the limited involvement of the local government. The tourism activities are still managed independently by the local community. Hence, the research aims to explore forms of local community participation to manage tourism potentials in Negeri Saleman. This research uses qualitative research methods with qualitative descriptive analysis techniques. Data collection conducted by field observations, in-depth interviews through purposive sampling technique with 7 informants, and literature review. The results show that the form of participation of the local community in Negeri Saleman is the main actor of tourism, such as providers of tourist accommodation services and typical souvenirs of the Negeri Saleman. In addition, there is also the role of local champions, namely traditional leaders and the Bapa Raja as the supervisors and controllers of tourism activities so that the sustainability of tourism activities can be guaranteed. The push factor for the involvement of local communities is economic factor related to the economic impact of tourism on improving the standard of living of local communities.

Keywords: tourism village, Central Maluku Regency, Negeri Saleman, community participation.

\section{LATAR BELAKANG}

Pariwisata merupakan sektor yang sedang digiatkan oleh pemerintah. Ini dikarenakan pariwisata adalah sektor yang memiliki multiplier effect. Sektor pariwisata tidak hanya berperan meningkatkan pertumbuhan ekonomi suatu wilayah, namun juga menciptakan lapangan kerja bagi berbagai pihak. Untuk mencapai tujuan tersebut, wisata perlu memiliki magnet kuat agar dapat menarik minat pengunjung sehingga perlu fasilitas dan atraksi wisata yang beragam (Chumsri et al., 2015).
Konsep pengelolaan pariwisata berbasis masyarakat adalah pendekatan bottom up yang ditujukan untuk meningkatkan partisipasi masyarakat dalam wisata. Konsep ini tidak hanya bertujuan untuk meningkatkan kualitas hidup masyarakat, namun juga menjaga keberlanjutan lingkungan, sosial, dan budaya pada lokasi wisata (Purmada et al., 2016). Melalui pariwisata berbasis masyarakat, diharapkan masyarakat dapat berpartisipasi dalam pengelolaan dan pengembangan wisata setempat dengan memperhatikan potensi lokal. Perlu ada upaya untuk memberikan pemahaman bagi masyarakat serta transfer pengetahuan dan pengalaman untuk 
meningkatkan kapasitas masyarakat (Jannah \& Suryasih, 2019).

Aspek kelembagaan adalah salah satu aspek penting dalam upaya pengembangan pariwisata. Kelembagaan dalam aktivitas pariwisata berperan penting sebagai penggerak, fasilitator, koordinator, dan pelaku utama wisata (Wijaya et al., 2020). Berbagai macam kelembagaan terdapat dalam wisata, meliputi pemerintah, swasta, masyarakat, akademisi, dan media. Masingmasing memiliki peran yang perlu dioptimalkan untuk menyukseskan pengembangan wisata.

Partisipasi masyarakat lokal dalam aktivitas pariwisata memiliki peran penting. Ini karena masyarakat lokal merupakan pelaku utama dari aktivitas wisata. Masyarakat tidak hanya berperan dalam pengelolaan kegiatan wisata, namun juga menyediakan atraksi wisata, menjamin kualitas produk wisata, bahkan dapat menjadi daya tarik wisata itu sendiri. Menurut Suswantoro (2004), partisipasi masyarakat dapat diwujudkan dalam dua bentuk, yaitu partisipasi aktif dan pasif. Partisipasi aktif berarti masyarakat terlibat secara langsung dalam aktivitas pariwisata karena didasari atas rasa memiliki. Sedangkan partisipasi pasif terkait dengan peran tidak langsung masyarakat dalam wujud dukungan-dukungan, seperti memelihara kondisi lingkungan. Munculnya partisipasi masyarakat dalam aktivitas wisata lebih dikarenakan adanya kemauan dari masyarakat untuk turut serta dalam aktivitas wisata. Lebih lanjut, Munawaroh (2017) memberikan gambaran mengenai partisipasi masyarakat dalam upaya pengembangan wisata berbasis masyarakat seperti partisipasi dalam bentuk pikiran, pendanaan, tenaga, dan keterampilan.

Partisipasi masyarakat lokal dalam aktivitas pariwisata tidak muncul begitu saja. Terdapat beberapa faktor yang mendorong keterlibatan masyarakat, baik secara aktif maupun pasif. Palimbunga (2017) menyebutkan bahwa faktor internal, seperti usia, tingkat pendidikan, jenis pekerjaan, dan kondisi penghasilan mempengaruhi keterlibatan masyarakat. Munawaroh (2017) menambahkan bahwa adanya kesadaran manfaat akan perubahan menuju lebih baik dan dapat meningkatkan taraf hidup dari aktivitas wisata itu sendiri mendorong masyarakat ikut berpartisipasi. Hal ini serupa dengan temuan Meray et al. (2016) bahwa faktor ekonomi sebagai sumber penghasilan dan menciptakan lapangan kerja bagi masyarakat lokal. Di sisi lain, inisiatif lokal dari para local champion perlu didorong agar dapat memberi pengaruh, menggerakkan, dan memberi perubahan bagi masyarakat (Musthofa, 2019). Selain itu, juga diperlukan beberapa terobosan untuk meningkatkan partisipasi masyarakat, seperti memberikan insentif dan mendorong terbentuknya kolaborasi yang baik antara pemerintah dan pihak lain (Widyawati, 2018).

Kabupaten Maluku Tengah adalah salah satu kabupaten yang berada di Provinsi Maluku. Kabupaten Maluku Tengah memiliki potensi wilayah berupa pertanian, perikanan dan pariwisata yang masih bersifat alami tanpa pengelolaan yang baik. Negeri Saleman merupakan salah satu wilayah yang terletak di Desa Sawai, Kecamatan Seram Utara, Kabupaten Maluku Tengah, Provinsi Maluku yang memiliki beragam potensi alam terutama wisata pantai dan wisata bahari.

Penelitian berlokasi di Negeri Saleman yang merupakan bagian dari Desa Sawai, Kecamatan Seram Utara, Kabupaten Maluku Tengah (Gambar 1). Secara administratif, Negeri Saleman terletak pada posisi $2,77^{\circ}-3,12^{\circ}$ Lintang Selatan dan $129,04^{\circ}-129,66^{\circ}$ Bujur Timur dengan luas wilayah $1.082,2 \mathrm{~km}^{2}$. Dilihat dari kondisi topografinya sebagian besar wilayah Kecamatan Seram Utara terdiri dari daerah pegunungan dan berbukit. Namun, wilayah ini juga memiliki potensi wisata bahari dan pantai yang menarik minat banyak wisatawan baik dalam maupun luar negeri, salah satunya adalah Pantai Ora yang popular menjadi tujuan wisata alam di Maluku.

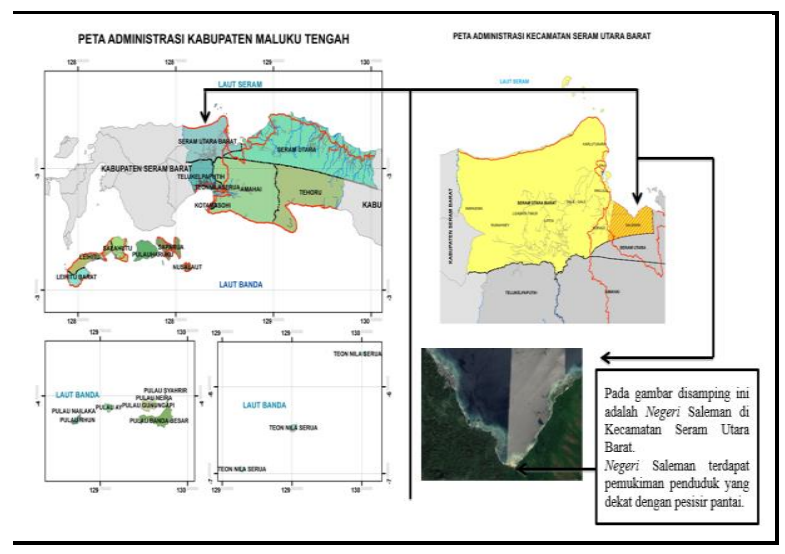

Gambar 1. Peta Lokasi Studi

Negeri Saleman memiliki potensi pertanian dan pariwisata sehingga sebagian besar penduduknya bekerja sebagai petani dan nelayan. Negeri Saleman juga menjadi lokasi dimana Pantai Ora berada, yang lokasinya dekat dengan perbukitan Hutan Nasional Manusela. Hal ini membuat negeri ini memiliki banyak potensi besar untuk dikembangkan menjadi desa wisata. Keunggulan Pantai Ora adalah pasirnya yang putih bersih, air laut yang berwarna biru jernih, serta kekayaan terumbu karang dan biota lautnya. 
Eksotisme Pantai Ora yang belum banyak tereksplorasi ini menjadi potensi besar untuk dapat dikembangkan sebagai tempat wisata unggulan di Indonesia, khususnya di bagian timur Indonesia.

Namun, terdapat permasalahan bahwa pengelolaan wisata di Negeri Saleman belum optimal. Objek wisata di Negeri Saleman belum dikelola oleh pemerintah daerah setempat. Potensi wisata yang ada masih dikelola secara mandiri oleh masyarakat sehingga masih terdapat kekurangan-kekurangan dalam pengelolaan. Kondisi ini dapat berdampak pada peluang terkait dampak positif ekonomi dari aktivitas wisata bagi masyarakat setempat dan aspek keberlanjutan lingkungan. Selain itu, lokasi wisata berdekatan dengan lokasi perbukitan Hutan Nasional Manusela yang masuk dalam kawasan lindung. Padahal, desa wisata perlu dikembangkan dengan melihat potensi lokal setempat dan perlu dijaga kelestarian dan karakteristik lokalnya. Ini dikarenakan dalam konsep pendekatan berbasis masyarakat, aspek kelestarian lingkungan juga perlu diperhatikan serta masyarakat lokal perlu dilibatkan baik sebagai subjek dan objek pembangunan (Herdiana, 2019).

Berdasarkan latar belakang tersebut, maka penelitian mengambil permasalahan yang terkait dengan partisipasi masyarakat sebagai aktor penting dalam mewujudkan pengelolaan desa wisata yang berkelanjutan. Dengan demikian, penelitian bertujuan untuk menggali bentukbentuk partisipasi masyarakat lokal dalam pengelolaan potensi wisata di Negeri Saleman.

\section{METODE PENELITIAN}

Penelitian dilakukan dengan menggunakan pendekatan penelitian kualitatif. Penelitian kualitatif adalah metode penelitian yang bersifat naturalistik karena berupaya untuk mengembangkan makna-makna yang diperoleh dari para partisipan serta menggunakan berbagai sumber data sehingga didapatkan pemahaman yang holistik (Creswell, 2014). Penelitian kualitatif dipilih karena penelitian bertujuan untuk menggali bentuk-bentuk partisipasi masyarakat dalam pengelolaan desa wisata yang hasilnya akan ditampilkan dalam bentuk deskriptif.

Pengumpulan data dilakukan dengan metode pengumpulan data primer melalui wawancara dan observasi lapangan serta metode pengumpulan data sekunder dengan telaah literatur. Wawancara mendalam (in-depth interview) dilakukan dengan teknik purposive sampling yang ditujukan kepada beberapa pihak, yaitu Dinas Pariwisata Kabupaten Maluku Tengah, tetua desa, kepala desa Negeri Saleman atau Bapa Raja, dan beberapa masyarakat lokal yang menjadi pelaku usaha wisata dengan total sampel sebanyak 7 informan. Wawancara dilakukan untuk menemukan berbagai potensi wisata yang ada di Negeri Saleman, bentukbentuk partisipasi/ keterlibatan masyarakat dalam pengelolaan wisata serta masalah dan tantangan dalam pengelolaan wisata berbasis partisipasi masyarakat. Sementara itu, observasi lapangan dilakukan untuk mengamati aktivitas masyarakat lokal terkait pariwisata di Negeri Saleman. Telaah literatur dilakukan dengan kompilasi berbagai informasi bersumber dari buku, surat kabar, artikel, arsip, dan gambar visual dari internet. Adapun data-data yang dikumpulkan dalam penelitian tersaji di Tabel 1 berikut.

Tabel 1. Tabel Kebutuhan Data

\begin{tabular}{|c|c|c|}
\hline Indikator & $\begin{array}{c}\text { Metode } \\
\text { Pengumpulan } \\
\text { Data } \\
\end{array}$ & Sumber Data \\
\hline $\begin{array}{l}\text { Potensi wisata di } \\
\text { Negeri Saleman }\end{array}$ & $\begin{array}{l}\text { Observasi, } \\
\text { wawancara, telaah } \\
\text { dokumen }\end{array}$ & $\begin{array}{l}\text { Bapa Raja dan } \\
\text { tetua desa Negeri } \\
\text { Saleman, Dinas } \\
\text { Pariwisata } \\
\text { Kabupaten } \\
\text { Maluku Tengah }\end{array}$ \\
\hline $\begin{array}{l}\text { Bentuk-bentuk } \\
\text { partisipasi } \\
\text { masyarakat dalam } \\
\text { pengelolaan potensi } \\
\text { wisata }\end{array}$ & $\begin{array}{l}\text { Observasi dan } \\
\text { wawancara }\end{array}$ & $\begin{array}{l}\text { Bapa Raja, tetua } \\
\text { desa Negeri } \\
\text { Saleman, } \\
\text { masyarakat pelaku } \\
\text { usaha wisata }\end{array}$ \\
\hline $\begin{array}{l}\text { Peluang dan } \\
\text { tantangan } \\
\text { keterlibatan } \\
\text { masyarakat }\end{array}$ & $\begin{array}{l}\text { Observasi dan } \\
\text { wawancara }\end{array}$ & $\begin{array}{l}\text { Bapa Raja, } \\
\text { masyarakat pelaku } \\
\text { usaha wisata }\end{array}$ \\
\hline $\begin{array}{l}\text { Karakteristik sosial } \\
\text { dan ekonomi } \\
\text { masyarakat (jumlah } \\
\text { penduduk, mata } \\
\text { pencaharian, } \\
\text { pendidikan, } \\
\text { pendapatan) }\end{array}$ & Telaah dokumen & $\begin{array}{l}\text { BPS Kabupaten } \\
\text { Maluku Tengah }\end{array}$ \\
\hline Kondisi fisik wilayah & Telaah dokumen & $\begin{array}{l}\text { BPS Kabupaten } \\
\text { Maluku Tengah }\end{array}$ \\
\hline
\end{tabular}

Analisis dilakukan dengan teknik analisis deskriptif kualitatif berdasarkan teknik analisis kualitatif yang diperkenalkan oleh Miles \& Huberman (1994). Adapun teknik analisis data yang dilakukan meliputi: 1) Reduksi data, dimana peneliti catatan lapangan dan transkrip wawancara yang selanjutnya dikode dan ditelusuri tema-tema dari hasil wawancara. Contoh pengkodean yang dilakukan peneliti adalah RHR W1 12112020, 15, dimana RHR merupakan kode nama informan, W1 adalah urutan wawancara dengan informan, 12112020 adalah tanggal dilakukannya wawancara, dan 1-5 merupakan urutan baris pernyataan pada transkrip wawancara. Tahap analisis selanjutnya adalah 2) Penyajian data yang dilakukan dengan deskriptif dilengkapi foto-foto hasil observasi. Tahap selanjutnya adalah 3) 
Pengambilan kesimpulan/ verifikasi yang dilakukan dengan teknik triangulasi data. Teknik triangulasi data dilakukan dengan menggunakan berbagai sumber data, yaitu wawancara, observasi, dan telaah literatur.

\section{HASIL DAN PEMBAHASAN}

\section{Potensi Wisata Kecamatan Seram Utara}

Kecamatan Seram Utara memiliki potensi wisata yang banyak. Namun, hingga kini sektor kepariwisataan nampaknya belum dikembangkan dan dimanfaatkan secara optimal oleh pemerintah daerah setempat. Beberapa objek wisata bahkan telah dikenal oleh wisatawan, baik domestik maupun mancanegara. Sebagian wilayah Kecamatan Seram Utara yang merupakan daerah kepulauan yang terdiri atas kawasan pulau-pulau kecil dan besar serta kawasan laut, sehingga pengembangan kepariwisataan lebih difokuskan pada objek wisata alam terutama wisata bahari dan wisata budaya.

Kegiatan wisata alam di Kecamatan Seram Utara terdiri atas wisata Bahari, seperti berlayar, memancing, menyelam (scuba diving), snorkling, dan berbagai aktivitas olah raga air lainnya, wisata pantai, wisata goa, dan wisata adventure untuk mengeksplorasi flora dan fauna, seperti wisata Pantai Ora, Goa Hatupia, Tebing Hatupia, dan Taman Nasional Manusela yang terdapat di Pulau Seram. Sementara itu, kegiatan wisata budaya, seperti tarian Cakalele dan tarian Sawat yang menjadi peninggalan budaya maupun ciri khas event untuk penjemputan tamu mancanegara dan lokal.

\section{Gambaran Desa Wisata Negeri Saleman}

Sebagai salah satu kampung adat, Negeri Saleman memiliki sejarah tersendiri dalam perkembangan permukimannya. Negeri Saleman adalah sebuah permukiman lama di Maluku Tengah yang memiliki banyak peninggalan sejarah Belanda. Negeri Saleman dipimpin oleh raja-raja (Bapa Raja) yang bersifat turun temurun dan saat ini telah mencapai generasi kesebelas. Mayoritas penduduknya beragama Islam yang ditandai dengan adanya masjid besar di negeri tersebut.

Negeri Saleman memiliki sistem pemerintahan berdasarkan hukum adat dengan sistem turun temurun serta mempunyai lembaga adat yang terdiri atas Kapitan yang dipegang oleh Soa Rumaolat, Maatoke yang dipegang oleh Soa Makuituin, Latunusan (Raja Tanah) dipegang oleh Aloatuan, Kewang dipegang oleh Makuituin.
Selain Kapitan besar ada juga Kapitan dari Soa Laluhun, Kapitan dari Soa Makuituin, Kapitan dari Soa Aloahit dan Kapitan dari Soa Upuolat. Oleh karena memiliki unsur kesejarahan yang tinggi, tetua adat juga berupaya melestarikannya dengan memberikan pemahaman kepada pada pemimpin Negeri Saleman secara turun temurun serta kepada masyarakat untuk dapat mengenal dan melestarikan sejarah yang dimiliki.

"Negeri Saleman termasuk sebuah permukiman tua di Maluku Tengah. Meski tua, tak banyak peninggalan sejarah seperti benteng Belanda atau rumah-rumah tua..." (HU W1 25022020, 1-10).

“...Negeri Saleman dikenal sebagai salah satu kampung Islam di wilayah Pulau Seram. Mayoritas penduduknya beragama Islam. Salah satu bukti, ada sebuah masjid yang sangat besar berdiri di kampung ini." (HU W1 25022020, 1-10).

"Salah satu negeri adat di Seram Utara terbukti dengan urutan pemerintahan Raja yang turun temurun dari dahulu sampai sekarang telah mencapai sebelas keturunan generasi pemerintahan..." (HU W1 25022020, 2-10).

Negeri Saleman memiliki beragam objek yang bisa dijadikan daya tarik wisata, seperti potensi alam, seni budaya, legenda, makananminuman lokal dan sebagainya. Objek-objek tersebut yang menjadi daya tarik utama mendatangkan pengunjung. Negeri Saleman memiliki keanekaragaman flora dan fauna yang unik. Negeri Saleman juga memiliki beranekaragam potensi wisata mulai dari wisata pantai, gunung, tebing, dan lainnya (Gambar 2).

“...Pesona wisata alam seperti
peggunungan, dataran tinggi, dataran
rendah, pantai, danau, dan sebagainya..."
(KL W2 26022020, 1-6).

Beragam potensi tersebut dipengaruhi oleh kondisi fisik suatu wilayah yang berbeda dengan wilayah lainnya. Hal ini dapat menjadi magnet untuk menarik wisatawan baik lokal dan mancanegara. Salah satu objek wisata yang popular dikunjungi di Negeri Saleman adalah Pantai Ora (Gambar 3). Selain keindahan pantainya, Pantai Ora juga memiliki daya tarik berupa resort yang mengapung di atas air. 


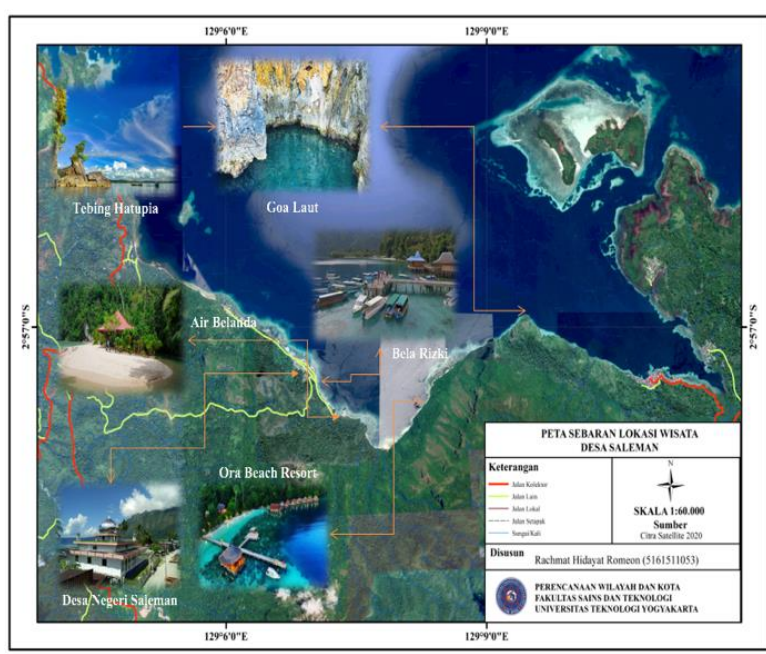

Gambar 2. Peta Sebaran Lokasi Wisata di Negeri Saleman

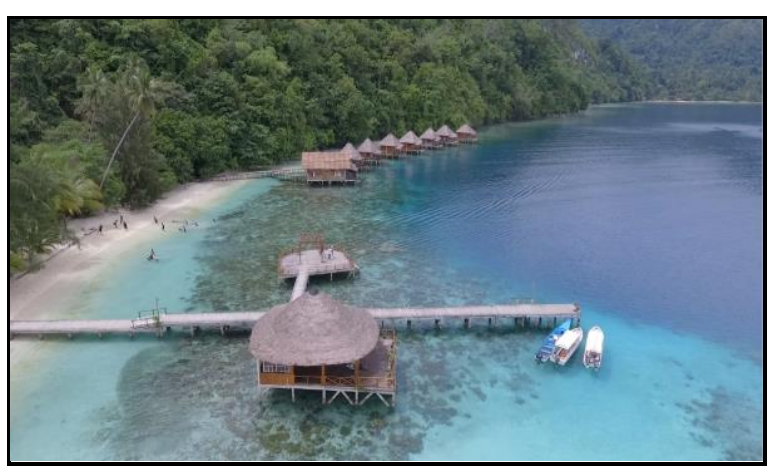

Gambar 3. Wisata Pantai Ora dengan Resortnya yang Terapung di Atas Air

Di sisi lain, kemunculan berbagai nama objek wisata di Negeri Saleman juga memiliki sejarah tersendiri yang perlu diceritakan kepada para pengunjung dan masyarakat lokal secara turun temurun. Untuk itu, diperlukan peran dari masyarakat lokal untuk dapat melestarikan budaya dan sejarah ini karena menjadi nilai tersendiri bagi perkembangan Negeri Saleman.

"Dulu pemuda-pemudi suka membuat makanan ika maki seperti ikan teri dan dicampur oleh bawang, chili, dan lemon nipis di sekitar lokasi itu..." (KL W2 26022020, 2-6).

“...Di kontrak tanah itu tahun 1995, masyarakat Negeri Saleman menceritakan ke pemilik Ora yang bernama Pak Wan, dan dinamakan Ora beach yang di ambil dari istilah oraora makanan. Mulai terkenal di tahun 2011 ..." (KL W2 26022020, 1-6).

“...Tebing batu dari zaman dulu, Namanya Hatupia yang dimana pia adalah batu sagu yang di ambil dari batu putih bahasa daerah. Gunung Roulessy dan burung Lusiala
Hatusaka keluar dari jam 6:20 pm dan masuk ke goa jam 5:00 am..." (Y W3 26022020, 2-6).

\section{Partisipasi Masyarakat Lokal dalam Pengelolaan Desa Wisata Negeri Saleman}

Bentuk partisipasi masyarakat lokal dalam pengembangan pariwisata diperlukan untuk dapat memberi dampak positif dan menjamin keberlanjutan aktivitas wisata yang ada. Namun demikian, bentuk-bentuk partisipasi masyarakat tersebut juga perlu diselaraskan dengan kondisi lokal masyarakat, seperti latar belakang kondisi sosial dan ekonomi yang turut mempengaruhi keterlibatan masyarakat (Palimbunga, 2017). Di sisi lain, partisipasi masyarakat bukan semata untuk menguatkan kapasitas masyarakat lokal, tetapi meningkatkan taraf hidup masyarakat lokal karena dampak dari pengembangan yang ada.

Partisipasi masyarakat lokal di Negeri Saleman terbagi menjadi dua, yaitu masyarakat lokal yang bermatapencaharian di sektor wisata serta peran dari tokoh adat dan Bapa Raja yang berperan sebagai local champion. Adapun partisipasi dari masing-masing pihak tersebut terjelaskan sebagai berikut.

a) Masyarakat lokal sebagai pelaku utama wisata

Masyarakat lokal sebagai pelaku utama wisata rata-rata bermatapencaharian sebagai pemilik resort. Resort terletak di pinggir pantai dan dilengkapi oleh fasilitas olahraga air. Resort yang disediakan berupa sebuah kamar di atas laut dengan ukuran $6 \times 6 \mathrm{~m}^{2}$ dengan harga sewa $\mathrm{Rp}$ $600.000,00$ per hari. Adapun kamar yang berukuran 4x3 $\mathrm{m}^{2}$ disewakan seharga $\mathrm{Rp}$ $500.000,00$ per hari. Hasil observasi juga menunjukkan berdasarkan kepemilikan resort dan homestay di Negeri Saleman, 9 dari 10 adalah milik masyarakat lokal. Kondisi ini menunjukkan bahwa masyarakat lokal memiliki kesadaran akan kebutuhan wisatawan terkait dengan jasa akomodasi berupa jasa penginapan.

Masyarakat lokal juga terlibat sebagai pemandu wisata objek wisata selain Pantai Ora, penyedia jasa spead boat dan mobil untuk wisatawan, penyewaan life jacket dan alat snorkling, serta penyedia lahan parkir kendaraan untuk wisatawan dan toilet umum (Gambar 4). Hal ini menunjukkan bahwa masyarakat lokal turut serta dalam penyediaan pelengkap wisata. 


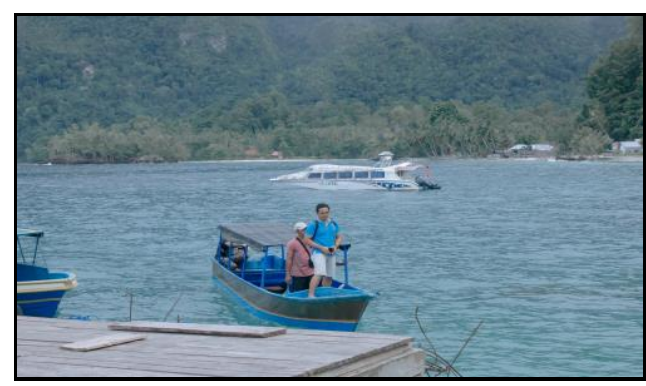

Gambar 4. Penyedia Jasa Spead Boat

Masyarakat lokal juga berperan sebagai penyedia ragam pangan lokal sebagai oleh-oleh, seperti ikan kering, dodol durian, dan sagu yang dijual ke wisatawan (Gambar 5). Aneka oleholeh ini menjadi ciri khas masyarakat Negeri Saleman. Selain itu, juga menjadi pedagang wisata kuliner di sekitar objek wisata yang menawarkan menu makanan lokal Negeri Saleman.

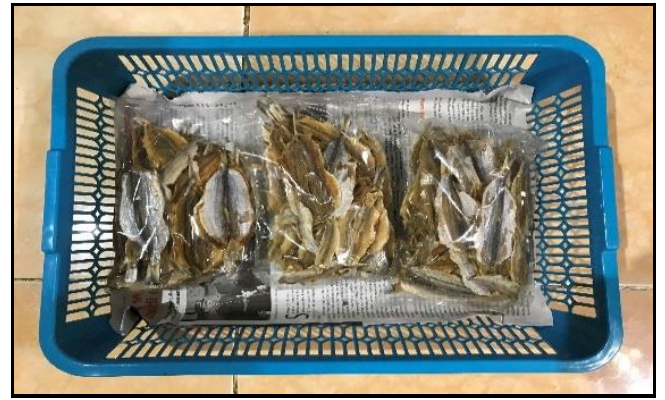

Gambar 5. Oleh-Oleh Ikan Kering

Munculnya berbagai aktivitas terkait wisata adalah dari inisiatif masyarakat sendiri dengan melihat potensi alam yang menarik dan menjadi daya tarik wisata. Adanya peluang ekonomi dari atraksi wisata pantai yang ada, masyarakat secara sadar memunculkan ide-ide kreatif dan mendorong keterlibatan sebagai pelaku usaha wisata sebagai penyedia jasa akomodasi. Tidak ada kecemburuan antar masyarakat dalam berperan mengelola desa wisata. Dengan adanya keterlibatan masyarakat lokal, masyarakat merasa senang karena bisa berbaur dengan para wisatawan dan memperkenalkan ciri khas dan potensi yang dimiliki. Di sisi lain, hal ini juga membantu masyarakat untuk meningkatkan perekonomian lokal dan mempromosikan desa wisata Negeri Saleman. Kondisi ini menggambarkan bahwa masyarakat lokal di Negeri Saleman termasuk berpartisipasi secara aktif (Suswantoro, 2004), dimana masyarakat berperan sebagai subjek dari aktivitas wisata itu sendiri.

"Inisiatif sendiri melihat situasi dengan cara membaur dan tangan terbuka. Dengan adanya Ora, masyarakat lokal dan sekitarnya terbuka pikirannya untuk membangun penginapan di atas laut dan di pesisir pantai Desa Saleman." (KL W2 26022020, 105-110).

"Setelah Pantai Ora terkenal, keindahannya dikagumi. Ibu Anna merasa senang dan bahagia, apalagi transaksi ekonomi di Desa Seleman juga ikut tumbuh. Banyak rumah makan, ada juga yang membuka penginapan dan kios-kios, penyewaan fasilitas pendukung wisata (spead boat, life jacket, alat untuk snorkling) serta travel tour." (Y W3 26022020, 120-129).

Partisipasi masyarakat sekitar Negeri Saleman merupakan hal yang penting ketika diletakkan atas dasar keyakinan bahwa masyarakat yang paling tahu apa yang dibutuhkan. Meskipun telah berpartisipasi aktif sebagai pelaku wisata, namun masyarakat lokal belum sepenuhnya dilibatkan dalam proses partisipasi aktif yang hakiki. Menurut Sunaryo (2013), partisipasi aktif masyarakat dalam aktivitas wisata diwujudkan melalui keterlibatan masyarakat mulai dari proses perencanaan, implementasi, dan monitoring serta evaluasi.

Terbatasnya keterlibatan pemerintah daerah serta pihak lain menjadikan potensi wisata di desa wisata Negeri Saleman belum dapat terkelola dengan baik karena belum memiliki rencana pengembangan yang jelas. Keterlibatan masyarakat dalam pengelolaan desa wisata masih sebatas menyadari potensi pengembangan, peluang, dan tantangan saat ini dan terlibat dalam tahap pelaksanaan saat ini, namun belum diwadahi oleh program-program pengembangan dan pengelolaan objek wisata yang jelas. Padahal keberadaan program-program pengembangan tersebut dapat menjadi bingkai bagi keberlanjutan aktivitas wisata kedepan, tidak hanya terkait aspek ekonomi dan sosial namun juga lingkungan.

“...Keikutsertaan masyarakat dalam
perencanaan desa wisata dapat mendorong
mereka berpartisipasi aktif dalam
pelaksanaan dan pengawasan..." (Y W3
26022020, 3-6).

b) Kelembagaan lokal: Tokoh adat dan Bapa Raja

Kelembagaan lokal berperan penting sebagai local champion untuk menggerakkan peran serta masyarakat lokal. Di Negeri Saleman, Bapa Raja dianggap sebagai pihak berpengaruh bagi pengembangan desa wisata karena menjadi pemimpin Negeri Saleman. Ini dikarenakan sistem 
pemerintahan Bapa Raja secara turun temurun dari sebelum zaman penjajahan dan memiliki lembaga adat, sehingga dapat dikatakan bahwa Bapa Raja sebagai local champion yang lebih bersifat formal. Keberadaan Bapa Raja juga didukung oleh adanya tetua adat sebagai local champion yang bersifat informal. Baik Bapa Raja dan tetua adat senantiasa berupaya memberi pemahaman bagi masyarakat lokal untuk melestarikan budaya dalam upaya pengembangan wisata di Negeri Saleman. Pemahaman dilakukan dengan media diskusi, pengarahan, dan sosialisasi bagi masyarakat lokal.

“...Dalam sosialisasi banyak cara yang digunakan selain melalui diskusi dan pengarahan oleh pemimpin Negeri Saleman..." (HU W1 25022020, 3-10).

“...Tentu saja cara yang dilakukan untuk memberikan saran/ pesan dengan sosialisasi dengan berbagai masyarakat maupun pimpinan Negeri Saleman sehingga dapat dinilai oleh masyarakat Negeri Saleman..." (HU W1 25022020, 23-10).

Adapun bentuk dukungan yang diberikan oleh tetua adat dan Bapa Raja dalam pengelolaan wisata di Negeri Saleman sebagai berikut:

1. Memberikan izin dan sebagai pengawas untuk memastikan seluruh aktivitas wisata yang berjalan sesuai dengan ketentuan desa, seperti larangan membuang sampah ke laut, kewajiban gotong royong untuk membersihkan kawasan pesisir pantai, dan menjaga tata tertib desa.

2. Memberikan rekomendasi ke pemerintah Kabupaten untuk membangun akses jalan, akses internet dan komunikasi di Negeri Saleman untuk mendukung pengelolaan wisata.

Musthofa (2019) mengatakan bahwa local champion lokal berperan dalam memobilisasi sumber daya di masyarakat karena memiliki daya tahan dan pengaruh yang kuat bagi masyarakat. Selain itu, local champion juga dapat berperan sebagai mediator untuk membangun jejaring antara masyarakat dengan stakeholder lainnya. Ini dikarenakan dalam prosesnya terdapat strategi komunikasi lokal yang intens dan terpercaya yang dapat dilakukan oleh local champion untuk mempengaruhi masyarakat dan membangun inisiasi lokal (Suryanto \& Trimarstuti, 2021). Lebih lanjut, lembaga lokal yang bersifat formal, seperti badan pariwisata desa juga dapat memberikan pelatihan dan transfer pengetahuan kepada masyarakat lokal (Suryaningsih \& Nugraha, 2018).

Pengelolaan desa wisata di Negeri Saleman dilakukan berdasarkan potensi objek wisata dan kesiapan masyarakatnya. Hal ini dapat dilihat dari upaya penyediaan fasilitas wisata dan usaha kuliner khas Negeri Saleman oleh masyarakat lokal. Masyarakat lokal berupaya secara aktif dalam pelaksanaan aktivitas wisata. Di sisi lain, jika dilihat dari aspek peningkatan kapasitas, partisipasi ini menjadi salah satu upaya untuk meningkatkan kemampuan, kreativitas, dan kompetensi masyarakat dalam pengembangan desa sesuai dengan potensi wisata yang dimiliki.

Keterlibatan masyarakat lokal dan local champion dalam aktivitas pariwisata tidak hanya membuka akses untuk memperoleh keuntungan finansial tetapi memberikan kesempatan untuk mengendalikan arah pengembangan objek wisata. Masyarakat lokal dapat berperan sebagai subjek dari aktivitas wisata, dimana masyarakat menemukenali potensi wisata yang ada lalu berupaya untuk mengembangkan usaha-usaha penunjang aktivitas wisata. Munculnya partisipasi ini dapat dikarenakan adanya motif yang melatarbelakanginya, utamanya motif ekonomi untuk meningkatkan taraf hidup masyarakat mengingat pariwisata memiliki multiplier effect yang besar. Kondisi ini sejalan dengan Anita \& Supriono (2018) yang menemukan bahwa faktor pendorong keterlibatan masyarakat dalam pariwisata adalah karena kepedulian, motivasi, dan motif dari masyarakat.

Sementara itu, local champion dapat berperan dalam aspek pengawasan pelaksanaan aktivitas wisata agar tetap memperhatikan kaidah yang diberlakukan serta keberlanjutan alam. Selain itu, local champion juga dapat menjadi jembatan penghubung antara masyarakat dengan pihak-pihak lain atau eksternal dalam upaya pengembangan desa wisata serta agen perubahan dengan mendorong terciptanya inisiatif lokal dan mendorong kemandirian masyarakat setempat (Musthofa, 2019). Namun, karena masyarakat sebagai pelaku utama wisata, diperlukan peran serta aktif dari tahapan perencanaan hingga pengembangan wisata. Masyarakat lokal juga diharapkan dapat mendukung segala bentuk program-program pengembangan wisata yang masuk dengan tetap mempertimbangkan nilainilai lokal yang dimiliki.

\section{KESIMPULAN}

Negeri Saleman memiliki beragam daya tarik wisata yang potensial untuk dikembangkan. Bentuk partisipasi masyarakat lokal Negeri 
Saleman dalam pengelolaan desa wisata adalah sebagai pelaku utama usaha wisata. Masyarakat lokal menyadari kekayaan potensi alam yang dimiliki dan berupaya untuk mengelola potensi tersebut melalui beragam usaha wisata, seperti jasa akomodasi, pedagang kuliner, dan lainnya. Local champion, yaitu tetua adat dan Bapa Raja juga turut berperan sebagai pengawas aktivitas wisata dan penghubung antara masyarakat dengan pihak eksternal untuk mengembangkan wisata di Negeri Saleman. Adapun faktor yang mendorong keterlibatan masyarakat tersebut lebih disebabkan oleh motif ekonomi untuk meningkatkan taraf hidup masyarakat.

\section{DAFTAR PUSTAKA}

Anita, D. M. D., \& Supriono, S. (2018). Analisis Partisipasi Masyarakat Lokal dalam Pengembangan Pariwisata di Pulau Gili Labak Kabupaten Sumenep. Jurnal Administrasi Bisnis, 61(4), 29-38.

Chumsri, P., Chanin, O., \& Sriprasert, P. (2015). Guidelines on Developing Community Base Tourism to Sustainable Management of Tourist Attractions. Journal of Economics, Business and Management, 3(6), 653-655. https://doi.org/10.7763/joebm.2015.v3.260

Creswell, J. W. (2014). Research Design: Qualitative, Quantitative, and Mix Methods Approaches (4th ed.). Sage Publications.

Herdiana, D. (2019). Peran Masyarakat dalam Pengembangan Desa Wisata Berbasis Masyarakat. Jurnal Master Pariwisata (JUMPA), 6(1), 63-86. https://doi.org/10.24843/jumpa.2019.v06.i0 1.p04

Jannah, H. R., \& Suryasih, I. A. (2019). Pengelolaan Desa Wisata Berbasis Masyarakat di Desa Mas, Ubud. Jurnal Destinasi Pariwisata, 7(1), 77-81. https://doi.org/10.24843/jdepar.2019.v07.i0 1.p12

Meray, J. G., Tilaar, S., \& Takumansang, E. D. (2016). Partisipasi Masyarakat Terhadap Pengembangan Pariwisata Pantai Mahembang Kecamatan Kakas. Spasial, 3(3), 47-55.

Miles, M. B., \& Huberman, M. (1994). Qualitative Data Analysis: An Expanded Sourcebook (2nd ed.). Sage Publications.

Munawaroh, R. (2017). Partisipasi Masyarakat dalam Pengembangan Pariwisata Berbasis Masyarakat di Taman Nasional Gunung Merbabu Suwanting, Magelang. Jurnal Elektronik Mahasiswa Pend. Luar Sekolah S1, 6(4), 374-389.
Musthofa, B. M. (2019). Strategi Mengembangkan Inisiatif dan Partisipasi Masyarakat Lokal untuk Mengembangkan Wisata Perdesaan bagi Peningkatan Kesejahteraan Masyarakat. Jurnal Vokasi Indonesia, $\quad 7(2), \quad 1-11$. https://doi.org/http://dx.doi.org/10.7454/jvi. v7i2.147

Palimbunga, I. P. (2017). Bentuk Partisipasi Masyarakat dalam Pengembangan Pariwisata di Kampung Wisata Tablanusu Kabupaten Jayapura Provinsi Papua: Kajian Pariwisata Budaya. MELANESIA: Jurnal Ilmiah Kajian Sastra Dan Bahasa, 01(02), 15-32.

Purmada, D., Wilopo, W., \& Hakim, L. (2016). Pengelolaan Desa Wisata dalam Perspektif Community Based Tourism (Studi Kasus pada Desa Wisata Gubugklakah, Kecamatan Poncokusumo, Kabupaten Malang). Jurnal Administrasi Bisnis, 32(2), 15-22.

Sunaryo, B. (2013). Kebijakan Pembangunan Destinasi Pariwisata: Konsep dan Aplikasinya di Indonesia. Gava Media.

Suryaningsih, O., \& Nugraha, J. T. (2018). Peran Lembaga Desa dalam Pengembangan Desa Wisata Wanurejo dan Dampaknya terhadap Perekonomian Masyarakat Lokal. Jurnal Mahasiswa Administrasi Negara, 02(01), 120-128.

Suryanto, E. F., \& Trimarstuti, J. (2021). Kelembagaan Lokal Desa sebagai Upaya Strategi Partisipasi Masyarakat dalam Pembangunan Desa (Studi Kasus Desa Nglanggeran, Kecamatan Patuk, Kabupaten Gunungkidul). Universitas Teknologi Yogyakarta.

Suswantoro, G. (2004). Dasar-Dasar Pariwisata. Penerbit Andi.

Widyawati, C. (2018). Peranan Partisipasi Masyarakat Lokal dalam Pengembangan Wisata Heritage di Trowulan. Jurnal Pariwisata, 5(2), 83-94. https://doi.org/https://doi.org/10.31294/par. v5i2.3489

Wijaya, M. I. H., Hutama, S. T. E. W., Dewi, Z. L., \& Puspasari, D. A. (2020). Peran Kelembagaan dalam Faktor Penarik Pariwisata Kabupaten Temanggung. Bhumiphala: Jurnal Pengembangan Dearah, 1(2), 27-35. 